\title{
EFFECTS OF SALINITY ON GROWTH AND PROLINE CONTENT ON BEAN AND ALFALFA
}

\author{
Sabah RAZI ${ }^{1, *}$, Fatima Zohra KHADHIR ${ }^{2}$ \\ `E-mail: sabah_razi@yahoo.fr, sabah.razi@univ-biskra.dz
}

Received: Mar. 02, 2021. Revised: June 15, 2021 Accepted: June 21, 2021. Published online: 28 June 2021

\begin{abstract}
Soil salinity is a major agricultural constraint in many countries. Plants' response to salinity depends on the species and the salt concentration in the soil. The objective of this study was to test the resistance of three leguminous plants common bean (variety 'El-Jadida'), broad bean (variety 'Claro de Luna'), and alfalfa (variety 'Diamon') - to several salinity rates and to show which one was more resistant to salt stress. This study was carried out under controlled conditions, with six $\mathrm{NaCl}$ concentrations $(0,1,3,6$, and $9 \mathrm{~g} / \mathrm{kg}$ ) added to a mixture of potting soil and sand. A completely randomised design was used, where the three legumes were cultivated with different salt concentrations to determine the effect of these doses on fresh biomass, dry mass, and physiological parameters (sodium and proline content). The results showed the negative effect of salinity on fresh biomass and dry mass of shoots and roots. Claro de Luna, the broad bean variety, was more adapted to salinity than alfalfa and common bean. The amount of sodium in the shoots and roots of the three species
\end{abstract}

increased with increasing salinity. Alfalfa may play a role in soil desalination; at $53.33 \mathrm{mM} \mathrm{NaCl}, 100 \mathrm{mg}$ alfalfa dry mass absorbed $4.5 \mathrm{mg} \mathrm{Na}$ per pot, which corresponded to the uptake of about $0.6 \mathrm{~kg}$ $\mathrm{Na}$ per hectare of soil. Proline content increased with increasing salt concentrations.

Keywords: salt stress; proline content; bean; alfalfa; phytoremediation.

\section{INTRODUCTION}

Salinity affects agricultural yield and quality in arid and semi-arid regions (Schulze et al., 2005). Soil is said to have become salinized when the salt concentration in the root zone reaches a level too high for optimum plant growth and production (Hanson et al., 2006). More than $20 \%$ of total cultivated lands in the world contain salt levels high enough to cause salt stress in cultivated plants (Hasanuz et al., 2013).

\footnotetext{
${ }^{1}$ Department of Agricultural Sciences, University of Biskra 07000, Algeria
} 
Salinity is becoming a serious agricultural problem, especially in irrigated lands located in semi-arid areas. High salt concentrations in the soil reduce the production of various plants around the world (Gorai and Neffati, 2007). Salts dissolved in soil water can reduce crop growth in two ways: by osmotic influences and by specific-ion toxicities (Hanson et al., 2006; Liang et al., 2018). Crop plants differ a great deal in their ability to survive and yield satisfactorily when grown in saline soils. Some plants evolved strategies to survive and reproduce under highly saline conditions, where most plants cannot. These plants are named 'halophytes,' and they represent only $1 \%$ of all plant species (Flowers and Colmer, 2008). However, halophytes are defined as having the ability "to complete the life cycle in a salt concentration of at least $200 \mathrm{~mm} \mathrm{NaCl}$ (> $200 \mathrm{mM} \mathrm{NaCl}$ ) under conditions similar to those that might be encountered in the natural environment" (Flowers et al., 1986). Most plants cannot withstand even low $(<40 \mathrm{mM} \mathrm{NaCl})$ salt concentrations (Munns and Tester, 2008).

The salt tolerance of halophytes varies among species and among different stages of a plant's life cycle, and the seed germination stage is generally considered more sensitive to salt than the mature plant growth stage for a given species (Khan et al., 2001).

It is important to determine the limit of salinity that crops can tolerate and determine whether they can uptake and accumulate salts to use them for soil desalination. This may encourage and motivate farmers to introduce these plants into their cropping system.

The goal of this study was to test the tolerance of three cultivated species of legumes to different salt concentrations and demonstrate which was more tolerant to salinity, how much salt they can accumulate, and the response to salinity by proline production.

\section{MATERIALS AND METHODS}

\section{Experimental plants and growth conditions}

Broad bean (Vicia faba, variety 'Claro de Luna,' from Spain, moderately sensitive to salt soils and largely cultivated in Biskra and arid regions with salt soils), alfalfa (Medicago sativa, variety 'Diamon,' from the USA, tolerant to salinity), and common bean (Phaseolus vulgaris, variety 'El djadida,' from Spain, sensitive to salinity) were selected as experimental plants for this study.

The experiment was conducted at a laboratory of the Department of Agricultural Sciences of the University of Biskra, Algeria, under controlled conditions, with a 16-hour photoperiod and temperature varying from 25 to $28^{\circ} \mathrm{C}$. Relative humidity was maintained at $60 \%$.

Plastic pots with a capacity of $5 \mathrm{~kg}$ were used. The bottom of each pot was perforated and lined with a layer of gravel to facilitate aeration. The seeds were cultivated in a substrate consisting of a mixture of sand and potting soil in a $1: 1$ ratio.

The potting soil was used to allow water retention and to provide the necessary nutrients to plants. It was composed of 100 to $150 \mathrm{mg} / \mathrm{kg}$ of nitrogen, 10 to $20 \mathrm{mg} / \mathrm{kg}$ of phosphorus, 100 to $150 \mathrm{mg} / \mathrm{kg}$ of potassium, 40 to $50 \mathrm{mg} / \mathrm{kg}$ of calcium, $10 \mathrm{mg} / \mathrm{kg}$ of 


\section{Sabah RAZI, Fatima Zohra KHADHIR}

magnesium, $86 \mathrm{mg} / \mathrm{kg}$ of sodium and 50 to $75 \mathrm{mg} / \mathrm{kg}$ of sulphates, with an electrical conductivity (EC) of 0.5 to $1 \mathrm{dS} / \mathrm{m}$ and a $\mathrm{pH}$ of 5.5 to 6.5 .

\section{Salt concentrations}

\section{and treatment preparation}

Six salt $(\mathrm{NaCL})$ concentrations were prepared: 0 (control), 7.11, 51.33, 102.66, 153.99, and 205.33 mM, which corresponded to $0.0,1,3,6,9$ and $12 \mathrm{~g} / \mathrm{kg}$, respectively.
To prepare these salt concentrations, $\mathrm{NaCl}$ was added to the substrate according to the salt concentration desired. When adding $\mathrm{NaCl}$, the same amount of substrate was removed from the pot, and then the salt was mixed with the substrate.

The electrical conductivity (EC) of prepared substrates with different $\mathrm{NaCl}$ concentrations were measured using an EC meter (one weight of substrate to five volume of distilled water) (Table 1).

Table 1 - Electrical conductivity (EC) of according to the amount of salt added to the substrate

\begin{tabular}{lcccccc}
\hline NaCl doses $(\mathbf{g} / \mathbf{k g})$ & 0 & 1 & 3 & 6 & 9 & 12 \\
\hline EC $(\mathbf{d S} / \mathbf{m})$ & 0.90 & 1.56 & 4.68 & 9.37 & 14.06 & 18.75 \\
\hline
\end{tabular}

\section{Seed sowing}

Intact and homogeneous seeds of the three species were chosen and filtered in distilled water for 7 hours to promote germination. The seeds were sown homogenously at a depth of $2 \mathrm{~cm}$, with 20 seeds per pot for common bean, five seeds per pot for broad bean, and 20 seeds per pot for alfalfa, to ensure good colonisation of the soil by plants. Immediately, the pots were irrigated to the holding capacity. Each pot was irrigated daily with potable water and maintained at $2 / 3$ of the holding water capacity during the test.

\section{Experimental design}

For all three experiments, a completely randomised design was adopted. With three independent replicates per treatment, each replicate consisted of one pot. Eighteen pots were tested for each plant species (six salt concentrations with three replicates for treatment for each plant species) (Fig. 1 and Fig. 2).

\section{Plant harvest}

The trial lasted 35 days until sufficient biomass was obtained. At the end of the experiment, plants from each treatment were harvested carefully, and roots were separated from shoots and washed quickly with distilled water to remove the rest of the substrate. Then, they were dried with a paper towel. Fresh biomass and the dry weight of plants was recorded under different salinity concentrations.

\begin{tabular}{|c|c|c|c|c|c|}
\hline $\mathrm{D}_{0}$ & $\mathrm{D}_{1}$ & $\mathrm{D}_{9}$ & & $\mathrm{D}_{3}$ & $\mathrm{D}_{6}$ \\
\hline$D_{12}$ & $\mathrm{D}_{0}$ & $\mathrm{D}_{6}$ & D & $\mathrm{D}_{9}$ & $D_{9}$ \\
\hline $\mathrm{D}_{3}$ & $D_{9}$ & $\mathrm{D}_{1}$ & & $\mathrm{D}_{0}$ & $D_{3}$ \\
\hline $\mathrm{D}_{0}$ & $D_{3}$ & $\mathrm{D}_{12}$ & & $\mathrm{D}_{1}$ & $\mathrm{D}_{12}$ \\
\hline $\mathrm{D}_{1}$ & $D_{12}$ & $\mathrm{D}_{6}$ & & $\mathrm{D}_{3}$ & $\mathrm{D}_{1}$ \\
\hline$D_{9}$ & $\mathrm{D}_{6}$ & $\mathrm{D}_{3}$ & & $\mathrm{D}_{9}$ & $\mathrm{D}_{12}$ \\
\hline \multicolumn{3}{|c|}{ Common bean } & \multicolumn{3}{|c|}{ Broad bean } \\
\hline & & $D_{3}$ & $\mathrm{D}_{0}$ & $D_{9}$ & \\
\hline & & $\mathrm{D}_{9}$ & $\mathrm{D}_{3}$ & $\mathrm{D}_{0}$ & \\
\hline & & $\mathrm{D}_{0}$ & $D_{12}$ & $D_{1}$ & \\
\hline & & $\mathrm{D}_{12}$ & $\mathrm{D}_{1}$ & $D_{3}$ & \\
\hline & & $\mathrm{D}_{1}$ & $D_{12}$ & $D_{6}$ & \\
\hline & & $\mathrm{D}_{9}$ & $D_{6}$ & $D_{6}$ & \\
\hline \multicolumn{5}{|c|}{ Alfalfa } & \\
\hline
\end{tabular}

Figure 1 - Experimental design ( $D_{0}=$ control, $D_{1}=1 \mathrm{~g} / \mathrm{kg}, D_{3}=3 \mathrm{~g} / \mathrm{kg}$, $D_{6}=6 \mathrm{~g} / \mathrm{kg}, D_{9}=9 \mathrm{~g} / \mathrm{kg}, D_{12}=12 \mathrm{~g} / \mathrm{kg}$ (g of $\mathrm{NaCl}$ per $\mathrm{kg}$ of substrate) 
The samples were weighed to obtain the weight of fresh biomass and then dried rapidly in an oven at $80^{\circ} \mathrm{C}$ until a stable weight was obtained. They were weighed again to obtain the weight of dry matter. For both shoots and roots, fresh material was analysed to determine the proline content, and dried material was analysed for sodium

\section{RESULTS}

\section{Effect of salt on fresh biomass and dry mass of aerial parts}

The data showed that the average fresh biomass and dry mass produced by the three crops were inversely proportional to the concentration of $\mathrm{NaCl}$.

For common beans, the shoot fresh biomass and dry mass were the highest in the control treatment, at 59.1 and $7.52 \mathrm{~g}$, respectively. It decreased at salt concentrations of 1,3 , and $6 \mathrm{~g} / \mathrm{kg}$. At $3 \mathrm{~g} / \mathrm{kg}$ treatment, the plant fresh biomass and dry mass were reduced (44.27 and $5.31 \mathrm{~g}$, respectively), which corresponded to 74.9 and $70.61 \%$ of the control weight. The plant withered at salt concentrations of 9 and $12 \mathrm{~g} / \mathrm{kg}$ (Fig. 2-a). The common bean was sensitive to increasing salt concentrations in the soil. It could not tolerate more than $6 \mathrm{~g} / \mathrm{kg} \mathrm{NaCl}$ (51.33 mM).

For the broad bean, the amount of fresh biomass and dry mass decreased with the increase in the concentration of $\mathrm{NaCl}$ in the substrate. Similar to common bean, a reduction of fresh biomass and dry mass of shoots was observed at a treatment of $3 \mathrm{~g} / \mathrm{kg}$ $\mathrm{NaCl}$, compared to the control treatment (estimated at $67.68 \%$ and
67.74\%, respectively). However, there was a weak production of dry mass at the $6 \mathrm{~g} / \mathrm{kg}(51.33 \mathrm{mM})$ and $9 \mathrm{~g} / \mathrm{kg}$ $(102.66 \mathrm{mM})$ concentrations of salt (Fig. 2-b). At these concentrations, this plant showed some resistance compared to the common bean.

For alfalfa, similar results were recorded as that for broad bean (Fig. 2-C). The average quantities of fresh biomass and dry mass were inversely proportional to the $\mathrm{NaCl}$ concentration in the substrate at a concentration of $3 \mathrm{~g} / \mathrm{kg} \mathrm{NaCl}$. The weight loss in these two treatments, compared to the control treatment, were 74.5 and $89.25 \%$, respectively. Plant production did not occur for the treatment with a $9 \mathrm{~g} / \mathrm{kg}$ salt concentration.

\section{Effect of salinity on fresh biomass and dry mass of roots}

Regarding fresh biomass and dry mass produced by the roots, a negative effect of salinity was recorded.

For common beans, the averages fresh biomass and dry mass produced were highest for the control, followed by the $1 \mathrm{~g} / \mathrm{kg}$ treatment and this weight decreased with the increase in salinity concentration. The weights recorded for 9 and $12 \mathrm{~g} / \mathrm{kg}$ concentrations were almost zero (Fig. 3-a).

For the broad bean, the average root fresh biomass and dry mass were 17.3 and $2.137 \mathrm{~g}$, respectively; these quantities decreased with the increase in salt concentration (Fig. 3-b).

Alfalfa presented the same results as that for broad bean, but no biomass was produced for the 9 and $12 \mathrm{~g} / \mathrm{kg}$ salt concentrations (Fig. 3-C) 


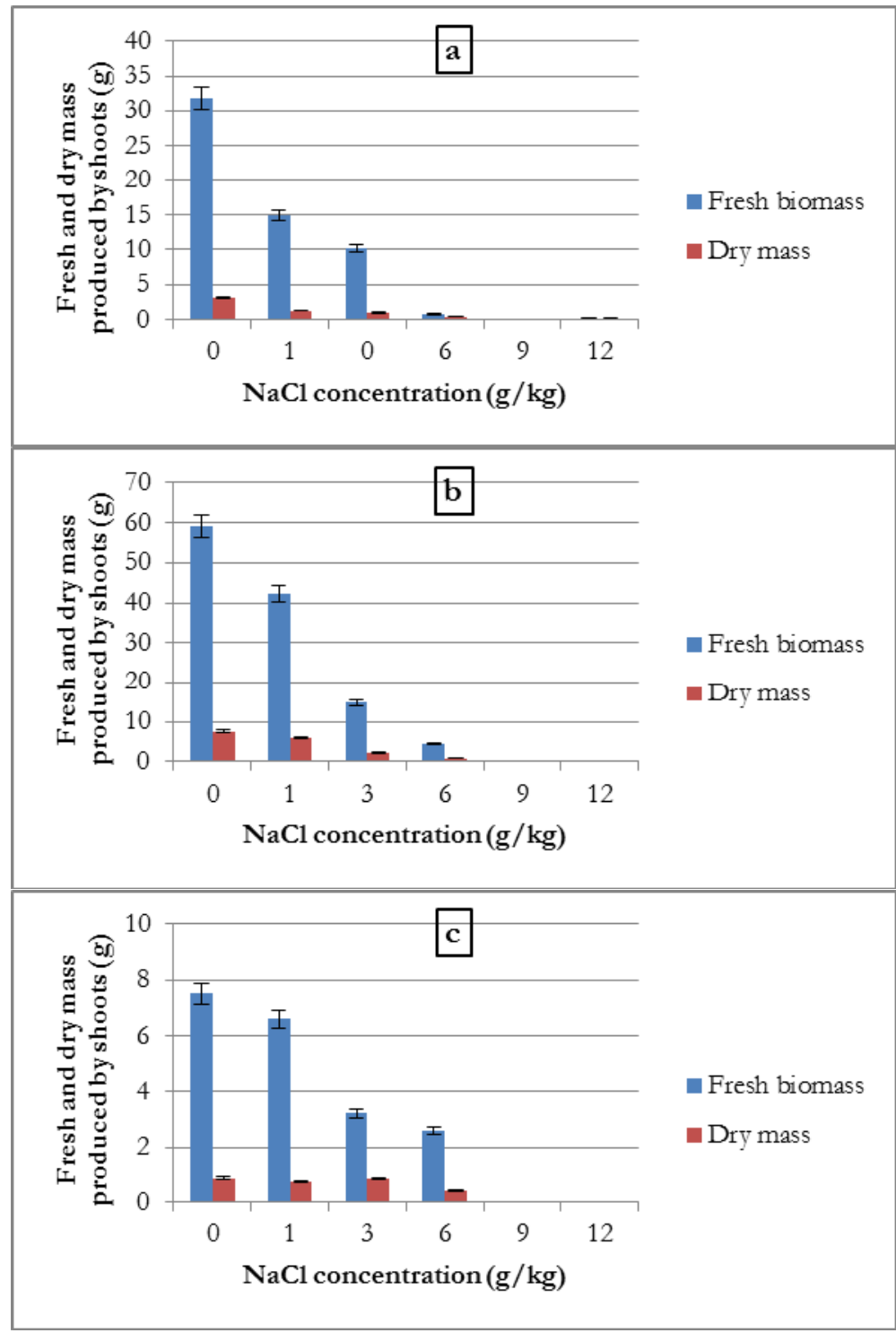

Figure 2 - Influence of salinity on the average amount of aerial fresh biomass and dry mass produced by common bean (a), by broad bean (b) and by alfalfa (c) 


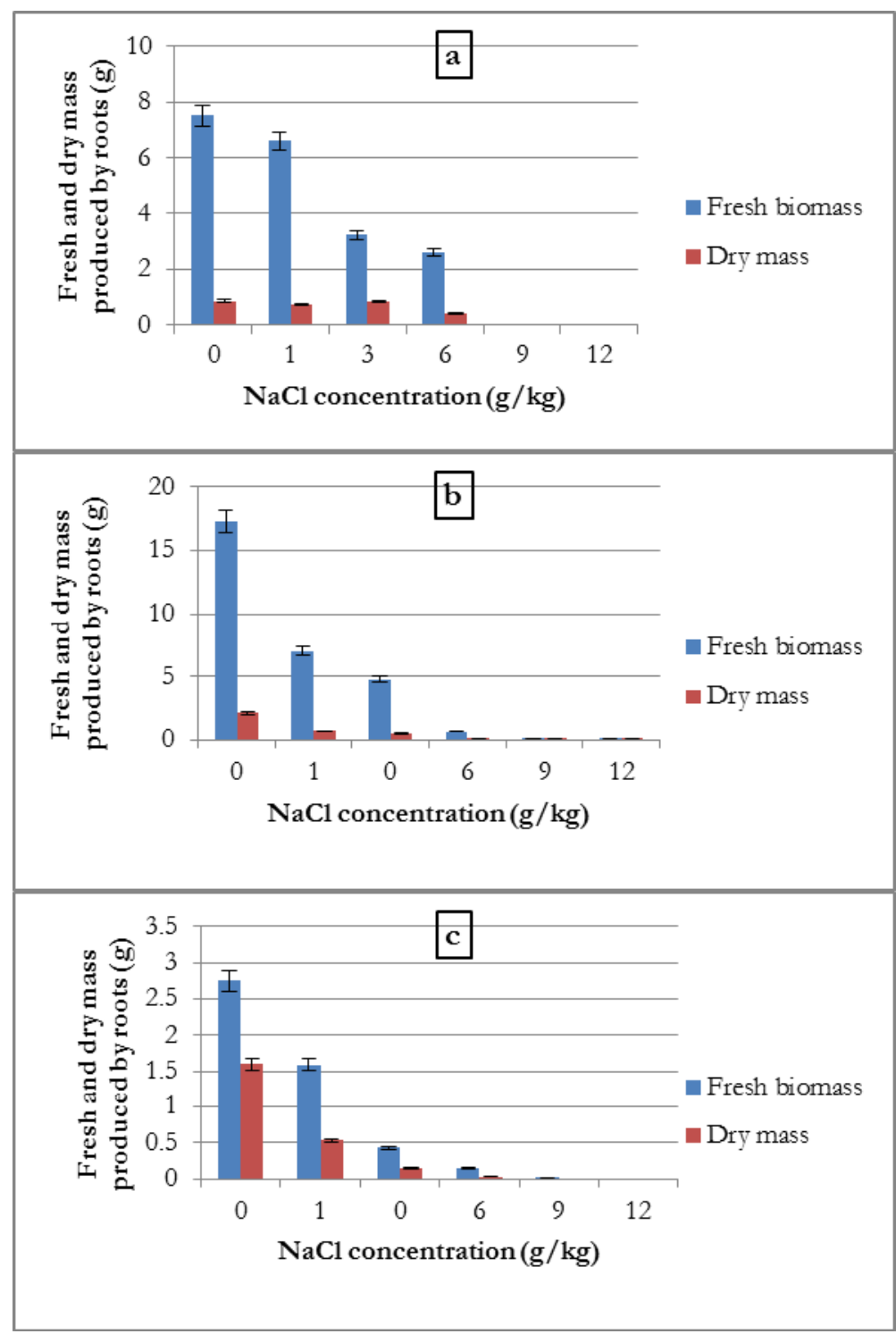

Figure 3 - Influence of salinity on the average quantities of fresh biomass and dry mass produced by the roots of common bean (a), broad bean (b) and alfalfa (c)

\section{Sodium content}

The sodium content in the aerial part of the roots was determined for the three plants. For common bean, the results showed that the roots contained more sodium than the aerial parts, and the sodium content increased with the increase in $\mathrm{NaCl}$ concentration up to $6 \mathrm{~g} / \mathrm{kg}$. At higher concentrations $(9$ and $12 \mathrm{~g} / \mathrm{kg}$ ), the sodium content decreased, but remained higher than that in the control treatment (Fig. 4-a). 


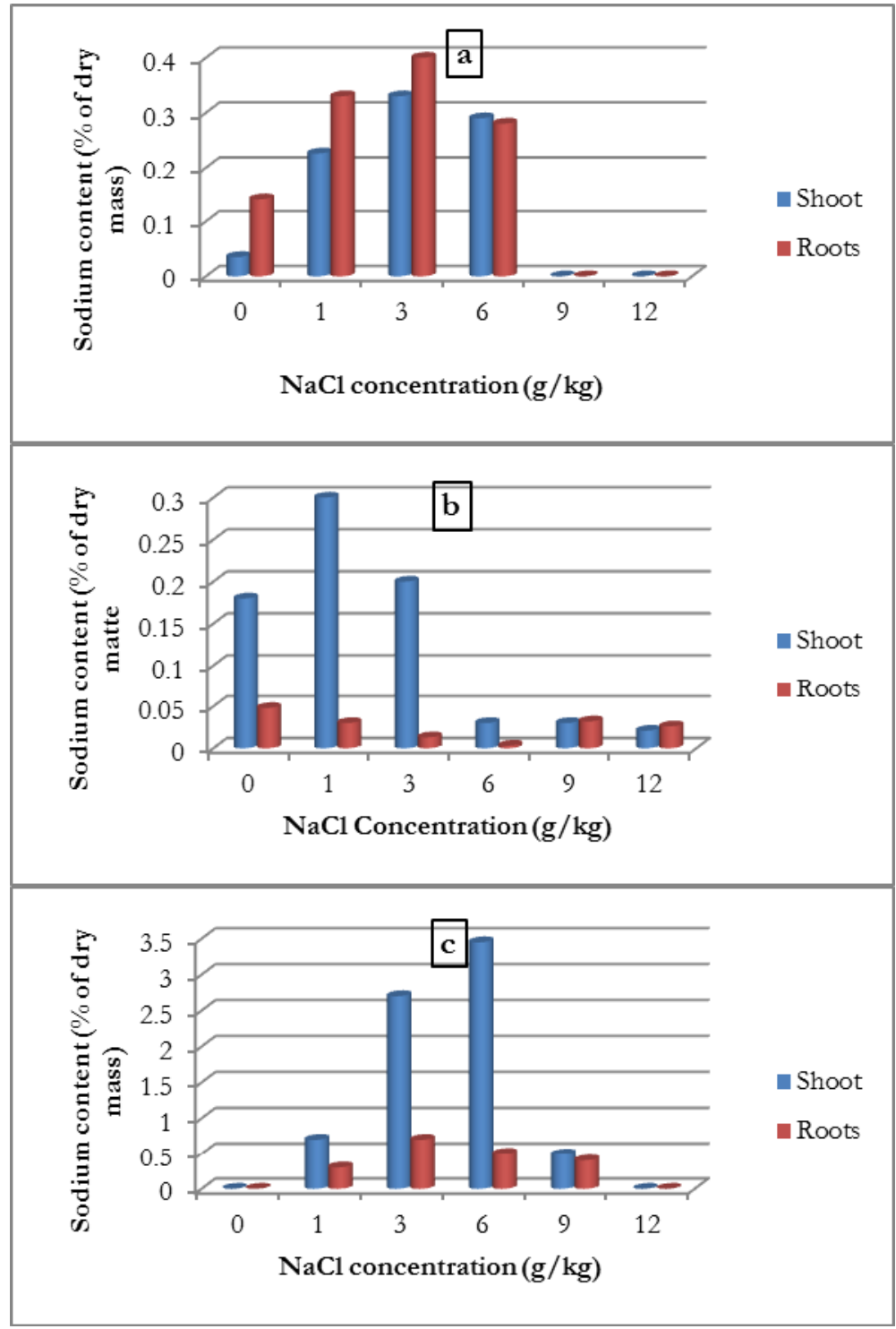

Figure 4 - Influence of salinity on the average sodium content of the shoots and roots of common bean (a), broad bean (b) and alfalfa (c)

For broad bean, the results were different; the sodium content of the aerial parts were higher than those of the roots, but increased with the $1 \mathrm{~g} / \mathrm{kg}$ concentration and then the sodium content decreased (Fig. 4-b).
For alfalfa, the results showed that the sodium content of the shoot parts were higher than those of the roots and increased with the increase in salinity concentration up to a $6 \mathrm{~g} / \mathrm{kg}$. At higher 
concentrations, the sodium content was 0 (Fig. 4-C).

\section{Proline content}

Only aerial parts were analysed for proline content. For high salt concentrations, we were unable to analyse and determine proline content due to the non-existent or very low quantities of biomass produced.

The analysis of proline content in plants grown in different $\mathrm{NaCl}$ concentrations showed that for common bean and alfalfa, the increase in proline content depended on the $\mathrm{NaCl}$ concentration (Fig. 5-a and 5-C).

Additionally, for the broad bean, proline content increased with $\mathrm{NaCl}$ concentration up to a $3 \mathrm{~g} / \mathrm{kg}$ concentration. At $6 \mathrm{~g} / \mathrm{kg}$ there was a decline in the proline content in the plant, which suffered from salinity stress (Fig. 5-b).

\section{DISCUSSION}

The obtained data showed that salinity negatively influenced the growth of all three legumes. Salt stress reduces plant growth (van Zelm et al., 2020). According to Rios-Gonzalez etal. (2002), salinity reduced aerial plant growth by inhibiting leaf initiation and expansion and reducing inter-node growth and accelerating leaf abscission. These results were confirmed by Zahran and Sprent (1986), who showed that, in legumes, salt stress of 50 to $200 \mathrm{mM} \mathrm{NaCl}$ significantly limits productivity. Several other studies have shown that fresh biomass and dry mass of roots were negatively affected by salinity (Bayuelo-Jimenez et al.,
2002). Bertrand et al. (2020), in their study about the effect of salt stress on several varieties of alfalfa, showed that the shoot biomass yield was reduced with an increase in $\mathrm{NaCl}$ concentration from 0 to $120 \mathrm{mM}$.

In this study, common bean showed a decrease and loss of growth under the effect of salinity $\geq 3 \mathrm{~g} / \mathrm{kg}$, which corresponds to $51.33 \mathrm{mM} \mathrm{NaCl}$. Additionally, according to Karabayetal. (2020), salt stress reduced shoot growth and biomass accumulation of common bean.

Huq and Larher (1984) showed that at a $50 \mathrm{mM} \mathrm{NaCl}$ concentration and an electrical conductivity of less than $2 \mathrm{dS} / \mathrm{m}$, growth was reduced by $50 \%$. The loss of plant growth may be explained by the inhibition of leaf growth in susceptible plants, which is the first response to excess salt in the medium (Munns and Termaat, 1986).

The presence of $\mathrm{Na}^{+}$ions in the cytosol inactivates several steps of photosynthesis, including electron transport (Allakhverdiev et al., 1999). A high concentration of $\mathrm{Cl}^{-}$causes the degradation of chlorophyll caused by the shrinkage of the membranes, which influences the production of plant organs. A significant reduction in fresh biomass and dry mass of root matter was recorded with the increase of salinity concentration, compared to fresh biomass and dry mass obtained in the control treatment. However, this reduction was greater in alfalfa, as was also recorded by Khan et al. (1994) for the same plant. 


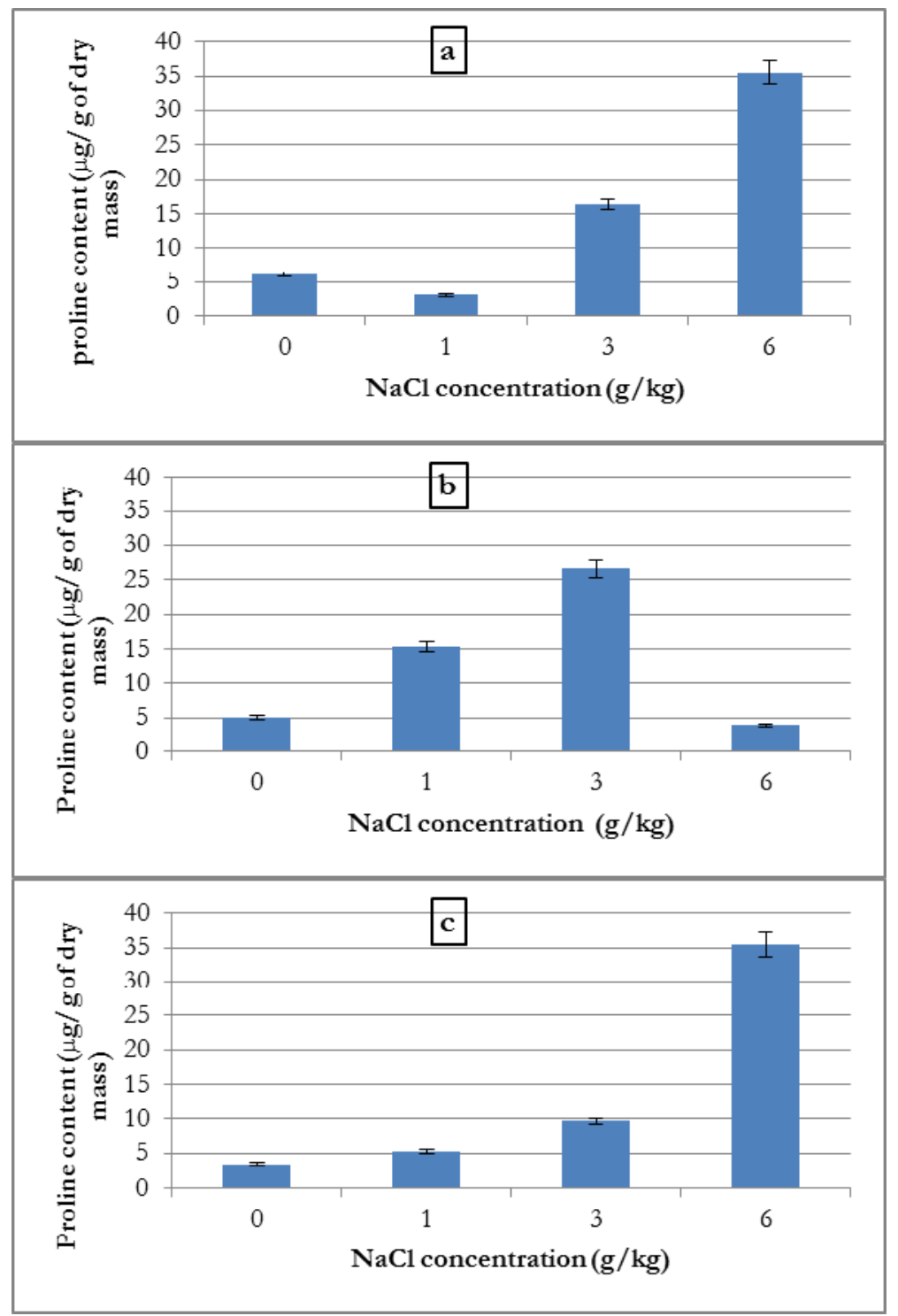

Figure $\mathbf{5}$ - Influence of salinity on the average proline content in common bean (a), broad bean (b) and alfalfa (c)

Furthermore, Hussain et al. (2002) reported that the total fresh biomass and dry mass production of Trifolium alexandrinum significantly decreased with increasing salinity.
Munns and Termaat (1986) demonstrated that the roots were less sensitive to salinity than the aerial parts of the plant, and they were only affected by high doses of salt, which is the case with 


\section{EFFECTS OF SALINITY ON GROWTH AND PROLINE CONTENT ON BEAN AND ALFALFA}

the concentration of $3 \mathrm{~g} / \mathrm{kg}$ of $\mathrm{NaCl}$ in this study.

In the presence of salt, the plant was under stress due to two main causes: the increase in the osmotic pressure of the roots' environment and the toxic effect generated by the high concentration of ions (Demir and Kocaçalişkan, 2002; Muchate et al., 2017). This led to a decrease in leaf growth. There was an increase in the internal concentration of $\mathrm{Na}^{+}$and $\mathrm{Cl}^{-}$, which are toxic to cells. Additionally, the high concentration of these two elements leads to an imbalance in the availability of nutrients, their absorption, and the plant's requirements for essential nutrients increase (Greenway and Munns, 1980). Munns and Tester (2008) demonstrated that the negative effect of salinity on plants that were initially grown with an osmotic stress component caused by the decrease of soil potential, which caused a restriction in the uptake of water by roots. Therefore, the water content decreased in plants.

Legumes generally responded to salinity by excluding sodium ions from their leaves. According to Munns (1992), the salt absorbed by plants indirectly controlled growth by affecting turgor, photosynthesis, and the activity of specific enzymes. First, growth is reduced by the decrease in the soil water potential; then, the leaves die because of the rapid increase in salt in the cell wall and cytoplasm.

Salt stress leads to water stress. The unavailability of water becomes a limiting factor for plants under saline conditions, which causes a "physiological drought". A decrease in the moisture content of the aerial parts was also observed with increasing salinity in chickpea cultivars by Gholipoor et al. (2001). Li et al. (2010) reported that low water content might not allow alfalfa to accumulate osmolytes.

The results showed that the increase in sodium uptake by the three tested plants depended on the $\mathrm{NaCl}$ concentration. In the presence of a high concentration of $\mathrm{NaCl}$, the plants absorbed increasing amounts of sodium. Fortmeier and Schubert (1995) indicated that the accumulation of excess sodium is highly toxic to the growth of corn.

Esechie et al. (2002) studied the effects of $\mathrm{NaCl}$ on the cationic balance of alfalfa (Medicago sativa L.) and observed that with increasing salt concentration, the $\mathrm{Na}$ concentration also increased in plant parts.

The sodium content of the aerial parts was not the same as those of the root parts. For common bean, the sodium content of the roots was higher than those of the aerial parts. Moreover, plants sensitive to salinity only accumulated low amounts of sodium in the leaves, which was the case in common bean. Slama (1987) indicated that this plant was very sensitive to salinity. The accumulation of $\mathrm{Na}^{+}$decreased in the following order: roots, stems, leaves. This plant is known to be 'exclusive' and excludes $\mathrm{Na}$ because it does not accumulate salts in the mesophile (Pan et al., 2011). 


\section{Sabah RAZI, Fatima Zohra KHADHIR}

The roots of sensitive plants were less efficient at introducing $\mathrm{Na}^{+}$into the xylem and more efficient at retaining it in their tissues than those of tolerant plants (Slama, 1987).

In saline soil, roots excluded all $\mathrm{Na}^{+}$and $\mathrm{Cl}^{-}$, while taking on water; they allowed only $2-3 \%$ to be transported through the xylem to the shoots (Munns et al., 2021). For broad bean and alfalfa crops, the results were different; more sodium was found in the aerial parts than in the roots. Therefore, these plants were tolerant to salinity and known as 'salt includer plants'.

The accumulation of sodium in the roots and shoots showed that plants may play a role in soil desalination. At $53.33 \mathrm{Mm} \mathrm{NaCl}, 100 \mathrm{mg}$ of common bean dry mass absorbed $0.4 \mathrm{mg} \mathrm{Na}$, broad bean absorbed $0.3 \mathrm{mg} \mathrm{Na}$, and alfalfa dry mass absorbed $3.45 \mathrm{mg} \mathrm{Na}$ per $100 \mathrm{mg}$ dry mass per pot $\left(572 \mathrm{~cm}^{2}\right.$ of pot surface), which corresponded to $0.6 \mathrm{~kg} \mathrm{Na}$ per hectare of soil and may be the most convenient to remove sodium. At a higher $\mathrm{NaCL}$ concentration, plant growth was very low, which may be inconvenient for plant cultivation even if the amount of sodium uptake is higher.

The tested legumes can contribute to desalination of soils, especially alfalfa, since they withstood certain doses of salinity; it is important to introduce these crops into cropping systems, as they are of economic importance and favourable to the nitrogen fertility of the soil (Kakraliya et al., 2018). Using plants to manage contaminated soils in general and soils affected by salinity has become an economically and environmentally acceptable strategy (Dickinson et al., 2009).

In general, an increase in the proline content was observed in the three plants with an increase in the $\mathrm{NaCl}$ concentration. Furthermore, to cope with salinity, the plants accumulated proline. Under saline stress, osmotic adjustment mechanisms by the accumulation of solutes (proline) were activated. The soluble proline content increased gradually and steadily with increasing salt stress levels. Proline has a role in strengthening the antioxidant system and fighting stress damage (Molinari et al., 2007). It could also intervene in the regulation of cytoplasmic $\mathrm{pH}$ (Pesci and Beffagna, 1986) or constitute a nitrogen reserve used by the plant after the period of stress (Tal and Rosenthal, 1979).

Maintaining cell turgor is an effective way to resist water stress. This mechanism results in an increase in the osmotic potential by an accumulation of osmolytes in the cytoplasm (Cushman and Bohnert, 2000). The modalities of osmotic adjustment vary depending on the variety and intensity of the stress applied (Blum, 1988). Proline is the most accumulated organic molecule in plants during stress (Nakashima et al., 1998). Proline plays an important role in protecting plants from osmotic stress. 


\section{EFFECTS OF SALINITY ON GROWTH AND PROLINE CONTENT ON BEAN AND ALFALFA}

\section{CONCLUSION}

This study showed that the increase of salinity negatively affects the growth of the three tested legumes (common bean, broad bean, and alfalfa). The three plants accumulated sodium and proline. At a $3 \mathrm{~g} / \mathrm{kg} \mathrm{NaCl}$ concentration, the plants were stressed.

The common bean (variety Eldjadia) showed some resistance to salinity, while the broad bean is a salttolerant plant and showed better resistance than alfalfa (variety Diamant antisale), but alfalfa absorbed more sodium and could be a solution for the remediation of salt-affected soils and may uptake $0.6 \mathrm{~kg}$ sodium from 1 ha of soil at a concentration of $3 \mathrm{~g} / \mathrm{l}$ of $\mathrm{NaCl}$.

Field studies must be carried out to confirm the obtained results, and further studies must be carried out to test the effect of other salt concentrations on the tested plants and on other crops and varieties to select the best plants for soil desalinisation.

\section{REFERENCES}

Alberico, G.J. \& Cramer, G.R. (1993). Is the salt tolerance of maize related to sodium exclusion? I. Preliminary screening of seven cultivars. J. Plant Nutr., 16(11): 2289-2303, DOI: 10.1080/01904169309364687

Acevedo, R., Morelock, J. \& Olivieri, R.A. (1989). Modification of coral reef zonation by terrigenous sediment stress. PALAIOS, 4(1): 92, DOI: $10.2307 / 3514736$

Allakhverdiev, S.I., Nishiyama, Y., Suzuki, I., Tasaka, Y. \& Murata, N. (1999). Genetic engineering of the unsaturation of fatty acids in membrane lipids alters the tolerance of Synechocystis to salt stress. Proc. Natl. Acad. Sci. USA, 96(10): 58625867, DOI: 10.1073/pnas.96.10.5862

Azevedo Neto, A.D. de, Prisco, J.T., Enéas-Filho, J., Lacerda, C.F. de, Silva, J.V., Costa, P.H.A. da \& Gomes-Filho, E. (2004). Effects of salt stress on plant growth, stomatal response and solute accumulation of different maize genotypes. Braz. J. Plant Physiol., 16(1): 31-38, DOI: 10.1590/s1677-04202004000100005

Bayuelo-Jiménez, J.S., Debouck, D.G. \& Lynch, J.P. (2002). Salinity tolerance in Phaseolus species during early vegetative growth. Crop Sci., 42(6): 2184-2192, DOI: $10.2135 /$ cropsci20 02.2184

Chaves, M.M., Flexas, J. \& Pinheiro, C. (2008). Photosynthesis under drought and salt stress: regulation mechanisms from whole plant to cell. Ann. Bot., 103(4): 551-560, DOI: 10.1093/aob/mcn125

Cordovilla, M.P., Ocaña, A., Ligero, F. \& Lluch, C. (1995). Salinity effects on growth analysis and nutrient composition in four grain legumes-rhizobium symbiosis. $J$. Plant Nutr., 18(8): 1595-1609, DOI: 10.1080/01904169509365006

Cramer, G.R., Läuchli, A. \& Polito, V.S. (1985). Displacement of Ca2+ by $\mathrm{Na}+$ from the Plasmalemma of root cells. Plant Physiol., 79(1): 207-211, DOI: 10.1104/pp.79.1.207

Cushman, J.C. \& Bohnert, H.J. (2000). Genomic approaches to plant stress tolerance. Curr. Opin. Plant Biol., $3(2)$ : 117-124, DOI: 10.1016/s13695266(99)00052-7

Demir, Y. \& Kocaçalişkan, I. (2002). Effect of $\mathrm{NaCl}$ and proline on bean seedlings cultured in vitro. Biol. Plant., 45(4): 597-599, DOI: 10.1023/a:1022343101727

Dickinson, N.M., Baker, A.J.M., Doronila, A., Laidlaw, S. \& Reeves, R.D. (2009). Phytoremediation of inorganics: realism and synergies. Int. 
J. Phytoremediation, 11(2): 97-114, DOI: $10.1080 / 15226510802378368$

Esechie, H.A., Al-Barhi, B., Al-Gheity, S. \& Al-Khanjari, S. (2002). Root and shoot growth in salinity-stressed alfalfa in response to nitrogen source. J. Plant Nutr., 25(11): 2559-2569, DOI: $10.1081 /$ pln-120014713

Flowers, T.J., Hajibagheri, M.A. \& Clipson, N.J.W. (1986). Halophytes. Q. Rev. Biol., 61(3): 313-337, DOI: 10.1086/415032

Fortmeier, R. \& Schubert, S. (1995). Salt tolerance of maize (Zea mays L.): the role of sodium exclusion. Plant Cell Environ., 18(9): 1041-1047, DOI: 10.1111/j.1365-3040.1995.tb00615.x

Gholipoor, M., Ghasemi-Golezani, K., Khooie, F.R. \& Moghaddam, M. (2001). Effects of salinity on initial seedling growth of chickpea (Cicer arietinum L.). Acta Agron. Hung., 48(4): 337-343, DOI: 10.1556/aagr. 48.2000.4.3.

Gorai, M. \& Neffati, M. (2007). Germination responses of Reaumuria vermiculata to salinity and temperature. Ann. Appl. Biol., 151(1): 53-59, DOI: 10.1111/j.1744-7348.20 07.00151.x

Greenway, H. \& Munns, R. (1980). Mechanisms of salt tolerance in nonhalophytes. Annu. Rev. Plant Physiol., 31(1): 149-190, DOI: 10.1146/annurev.pp.31.060180.0010 53

Hamza, M. (1978). Influence du régime d'apport du $\mathrm{NaCl}$ au milieu sur la régulation du bilan hydrique et de la teneur ionique chez une espèce tolérante, l'Hedysarum carnosum Desf., et une espèce sensible, le Haricot, Phaseolus vulgaris L. B. Soc. Bot. Fr.-Actual., 125(3-4): $177-$ 187, DOI: 10.1080/01811789.1978. 10826356

Hanson, B.R., Hutmacher, R.B. \& May, D.M. (2006). Drip irrigation of tomato and cotton under shallow saline ground water conditions. Irrig. Drain. Syst., 20(2-3): 155-175, DOI: $10.1007 / \mathrm{s} 10795-005-9000-9$
Hasanuzzaman, M., Nahar, K. \& Fujita, M. (2012). Plant response to salt stress and role of exogenous protectants to mitigate salt-induced damages. In book: Ecophysiology and Responses of Plants Under Salt Stress, 25-87, DOI: 10.1007/978-14614-4747-4 2

Hussain, N., Mujeēb, F., Tahir, M., Khan, G.D., Hassan, N.M. \& Bari, A. (2002). Effectiveness of Rhizobium under salinity stress. Asian J. Plant Sci., 1(1), 12-14, DOI: 10.3923/ajps.2002.12.14

Imamul Huq, S.M. \& Larher, F. (1984). Osmoregulation in higher plants: Effect of maintaining a constant $\mathrm{Na}: \mathrm{Ca}$ ratio on the growth, ion balance and organic solute status of $\mathrm{NaCl}$ stressed cowpea (Vigna sinensis L.). Z. Pflanzenphysiol., 113(2): 163-176, DOI: 10.1016/s004 4-328x(84)80051-3

Khan, M.G., Silberbush, M. \& Lips, S.H. (1994). Physiological studies on salinity and nitrogen interaction in alfalfa. II. Photosynthesis and transpiration. J. Plant Nutr., 17(4): 669-682, DOI: 10.1080/0190416940 936475737

Li, R., Shi, F., Fukuda, K. \& Yang, Y. (2010). Effects of salt and alkali stresses on germination, growth, photosynthesis and ion accumulation in alfalfa (Medicago sativa L.). Soil Sci. Plant Nutr., 56(5): 725-733, DOI: 10.1111/j.1747-0765.2010.00506.x

Liang, W., Ma, X., Wan, P. \& Liu, L. (2018). Plant salt-tolerance mechanism: A review. Biochem. Biophys. Res. Commun., 495(1): 286-291, DOI: 10.1016/j.bbrc.2017. 11.043

Molinari, H.B.C., Marur, C.J., Daros, E., de Campos, M.K.F., de Carvalho, J.F.R.P., Filho, J.C.B., ... Vieira, L.G.E. (2007). Evaluation of the stress-inducible production of proline in transgenic sugarcane (Saccharum spp.): osmotic adjustment, chlorophyll fluorescence and oxidative stress. 


\section{EFFECTS OF SALINITY ON GROWTH AND PROLINE CONTENT ON BEAN AND ALFALFA}

Physiol. Plant., 130(2): 218-229, DOI: 10.1111/j.1399-3054.2007.00909.x

Munns, R. \& Termaat, A. (1986). Wholeplant responses to salinity. Funct. Plant Biol., 13(1): 143, DOI: 10.1071/pp9860143

Munns, R. (1992). A leaf elongation assay detects an unknown growth inhibitor in xylem sap from wheat and barley. Funct. Plant Biol., 19(2): 127, DOI: 10.1071/pp9920127

Munns, R. \& Tester, M. (2008). Mechanisms of salinity tolerance. Annu. Rev. Plant Biol., 59(1): 651681, DOI: 10.1146/annurev.arplant. 59.032607.092911

Muchate, N.S., Nikalje, G.C., Rajurkar, N.S., Suprasanna, P. \& Nikam, T.D. (2016). Plant salt stress: Adaptive responses, tolerance mechanism and bioengineering for salt tolerance. Bot. Rev., 82(4): 371-406, DOI: 10.1007/ s12229-016-9173-y

Nakashima, K., Satoh, R., Kiyosue, T., Yamaguchi-Shinozaki, K. \& Shinozaki, K. (1998). A gene encoding prroline dehydrogenase is not only induced by proline and hypoosmolarity, but is also developmentally regulated in the reproductive organs of Arabidopsis. Plant Physiol., 118(4): 1233-1241, DOI: 10.1104/pp.118.4.1233

Pan, T., Li, W. \& Chen, Y. (2011). The influence of salt stress on the accumulation of $\mathrm{Na}+$ and $\mathrm{K}+$ in Tamarix hispida. Procedia Environ. Sci., 10: 1445-1451, DOI: 10.1016/ j.proenv.2011.09.231

Pesci, P. \& Beffagna, N. (1986). Influence of exogenously supplied potassium and sodium salts on the abscisic acid-induced proline accumulation in barley leaf segments. Physiol. Plant., 67(2): 123-128, DOI: 10.1111/j.13993054.1986.tb02432.x

Rios-Gonzalez, K., Erdei, L. \& Lips, S.H. (2002). The activity of antioxidant enzymes in maize and sunflower seedlings as affected by salinity and different nitrogen sources. Plant Sci.,
162(6): 923-930, DOI: $10.1016 / \mathrm{s} 0168$ $-9452(02) 00040-7$

Salama, K.H.A., Mansour, M.M.F., Ali, F.Z.M. \& Abou-hadid, A.F. (2007). $\mathrm{NaCl}$-induced changes in plasma membrane lipids and proteins of Zea mays L. cultivars differing in their response to salinity. Acta Physiol. Plant., 29(4): 351-359, DOI: 10.1007/ s11738-007-0044-3

Slama, F. (1987). Recherches sur les causes de l'exclusion du sodium des feuilles des plantes sensibles à $\mathrm{NaCl}$. Agron., 7(7): 517-522, DOI: 10.1051/agro: 19870707

Serraj, R. \& Sinclair, T.R. (2002). Osmolyte accumulation: can it really help increase crop yield under drought conditions? Plant Cell Environ., 25(2): 333-341, DOI: 10.1046/j.1365-3040.2002.00754.x

Tal, M., Rosental, I., Abramovitz, R. \& Forti, M. (1979). Salt tolerance in Simmondsia chinensis: Water balance and accumulation of chloride, sodium and proline under low and high salinity. Ann. Bot., 43(6): 701-708, DOI: 10.1093/oxford journals.aob.a085683

Tavakkoli, E., Fatehi, F., Coventry, S., Rengasamy, P. \& McDonald, G.K. (2011). Additive effects of $\mathrm{Na}+$ and $\mathrm{Cl}$-ions on barley growth under salinity stress. J. Exp. Bot., 62(6): 2189-2203, DOI: 10.1093/jxb/erq422

Zahran, H.H. \& Sprent, J.I. (1986). Effects of sodium chloride and polyethylene glycol on root-hair infection and nodulation of Vicia faba L. plants by Rhizobium leguminosarum. Planta, 167(3): 303-309, DOI: 10.1007/bfO 0391332

Zörb, C., Noll, A., Karl, S., Leib, K., Yan, F. \& Schubert, S. (2005). Molecular characterization of $\mathrm{Na}+/ \mathrm{H}+$ antiporters ( $\mathrm{ZmNHX)}$ of maize (Zea mays L.) and their expression under salt stress. J. Plant Physiol., 162(1): 55-66, DOI: 10.1016/j.jplph.2004. 03.010 